\title{
Polymerization of Aldehyde with Solid Catalyst
}

\section{Polymerization of Acetaldehyde with Metal Sulfate-Sulfuric Acid Complexes}

\author{
By Hiroshi Takida* and Ken Noro*
}

Polymerization of acetaldehyde was carried out by using metal sulfate-sulfuric acid complexes as catalyst. Effect of catalyst concentration on the polymerization was not remarkable in the range of $0.05 \sim 1.0 \%$. The rate of polymerization was relatively rapid and the critical temperature above which high polymer could not be obtained was observed between -30 and $-50^{\circ} \mathrm{C}$

It was possible to polymerize acetaldehyde in the presence of solvents or vinyl monomers, but copolymers of acetaldehyde, with vinyl monomers were not detected by measurement of infrared spectra. By dispersing the solid catalyst, degree of polymerization of polyacetaldehyde was increased remarkably, e.g., polymer having degree of polymerization above 30000 was obtained in high conversion.

Polymerization was retarded by basic compounds. It was suggested that the polymerization proceeds by cationic mechanism in liquid state. From the results of infrared spectra and $\mathrm{X}$ ray diffraction pattern, the polymer was confirmed to be amorphous.

第 2 報 金属硫酸塩-硫酸錯合体によるアルデヒド類の重合

(1963 年 3 月 7日受理)

滝田博**. 野呂健**

\begin{abstract}
要旨硫酸マグネシウムー硫酸錯合体を触媒として, n-プチルアルデヒド, iso-ブチルアルデヒド, お よびメトキシブチルアルデヒドの重合を $-30 \sim-78^{\circ} \mathrm{C}$ の温度筑囲にわたって娭即した。 $-30^{\circ} \mathrm{C}$ に㧍ける 重合では, iso-ブチルアルデヒドが少量のポリマーを与えるのみで, 他のアルデヒドではポリマーが得られな かった。 -78 $\mathrm{C}$ の重合では $n$ - および iso-ブチルアルデヒドは比較的高重合率でポリマーを与えるが, メト キシブチルアルデヒドでは，低重合率に止まる。触媒盟 $0.1 \sim 1.0 \%$ の籛囲では，一般に重合に著しい影響は みられず，重合速度はかなり早い。また，触媒の分散によりポリマーの粘度はやや上年するが，アセトアルデ ヒドの重合にみられるほど影著ではない。メキシブチルアルデヒドのポリマーは、比較的広範な溶媒に可溶 な粘着性弹性体であり，非晶性であると考えられるが，n-括よび iso-ブチルアルデヒドのポリマーは溶解性 に乏しく，X 線回折の結果からもこれら両者は結晶性であるとみられる。なお, クロラール，アクロレイン， およびクロトンアルデヒドは、この触媒により重合が悐めら机なかった。
\end{abstract}

\section{1. 緒亭}

高級アルデヒド類の重合に関しては, 高圧重合 ${ }^{1) \sim 8)}, ル$ イス酸触媒による重合7)，ポリリン酸-アミン系触媒によ る重合 ${ }^{8)}$ ，有機金属化合物を触媒とする重合 ${ }^{9), 10) ， お よ ひ ゙ ~}$ 金属アルコキシドによる重合》などが知られている。

われわれは，さきに，金属硫酸塩一硫酸錯合体を触媒に 用いると, 比較的早い重合速度で, 高重合萃に, ア七卜 アルデヒドポリマーの得られることを認め, また, 触媒
を分散せしめることにより,重合度 30000 以上のポリマ 一の得られることも認内た。この触媒は，比較的少量で 有効化重合可能であり, 諸実験事実を総合して, 液状力 チオン重合であろらと推察した ${ }^{11}$ 。

本研究において，われわれは主としてブチルアルデヒ ド類を中心に, 金属硫酸塩一硫酸錯合体による重合を行な い,その重合能を検討した。なお,ブチルアルデヒド類以 外にも, 二三のアルデヒドについて重合実験を試み，あ わせて得られたポリマーについて若干の知見を求めた。

* Central Research Laboratory, The Nippon Synthetic Chemical Industry Co., Ltd. (156, Kamikema, Amagasaki, Hyogo)

** 日本合成化学工業株式会社中央研究所(兵庫紧尼崎市上食満 156) 


\section{2. 実験}

\section{1 試 薬}

n- および iso-ブチルアルテヒト, クロトンアルデヒ

ト市販品在無水ボウ硝で脱水後精留した。

メトキシブルアルデヒドクロトンアルデヒド| メタノール $=1 / 3$ (モル) の混合物に, 触媒として $N / 10$ $\mathrm{NaOH}$ 水溶液を滴下し, 微アルカリ性において, 泠却 下, $5 \sim 10^{\circ} \mathrm{C}$ において合成した。反応中は, 絶えず反応 系をチェックし，常に微アルカリ性に保った。4 時間反 応後, まず $30^{\circ} \mathrm{C}$ で減圧フラッシュを行ない, さらに $10 \sim 20^{\circ} \mathrm{C}$ で, 隇圧下脱メタノールを行なった後, 減王精 留 $\left(50 \sim 52^{\circ} \mathrm{C} / 50 \mathrm{~mm}-\mathrm{Hg}\right)$ して使用に供した。

クロラール 市販品無水ボウ硝で脱水後减圧踋留 した。

アクロレイン 市販品の減圧精留を 2 回くり返し た。

溶媒およひヒヒニルモノマー 前報 ${ }^{11}$ 記载の方法によ り精製した。

\section{2 重合菨置と重合操作}

アルデヒド, 溶媒とも前報 ${ }^{11}$ の溶媒仕込装置在用いて, 真空下に仕込んだ。

重合操作も前報 ${ }^{11}$ 同様である。重合終了後, $n$-ブチル アルデヒドポリマーは, 冷却下 $1 \%$ の j-ナフチルアミ ンを含むクロロホルムに溶解, 微量つアンモニアを含む 蒸留水で沈殿しメトキシブチルアルデヒドポリマー は $1 \%$ のぶーナフルルミンを溶かしたアンモニア性メ タノールに治却下湥解し，上と同様に沈殿せしめた。沈
殿後のポリマーは蒸留水で数回洗浄後, 室温で真空乾燥 した。

\section{3 触媒の調製}

前報 ${ }^{11}$ 記載の方法により, 硫酸マグネシウム一硫酸錯合 体を作製した。

\section{4 粘度測定}

n-ブチルアルデヒドポリマーは, $2 \%$ の $\hat{\%}$ ーナフチル アミンを含むクロロホルムに溶解し, 濃度 $0.5 \mathrm{~g} / 100 \mathrm{ml}$ における $\eta_{s p} / c$ 值を $20^{\circ} \mathrm{C}$ において求めた。メトキシ プチルアルデヒドポリマーはメチルエチルケトン溶液と し, $27.6^{\circ} \mathrm{C}$ に捺いて粘度測定を行ない, 四式外插法に より [ク]求めた。

\section{5 ポリマーの構造の検討}

赤外吸収スペクトルおよび X 線回折の測定によった。 赤外吸收スペクトルの測定は, メトキシブチルアルデヒ ドポリマーについては, $\mathrm{NaCl}$ 上にフィルム状として測 定を行ない, $n$ - および iso-ブチルアルデヒドのポリマ 一は $\mathrm{KBr}$ 錠剤法によった。X 線回折は計数管により回 折强度曲線を求めた。

\section{3. 結 果}

\section{1 重 合}

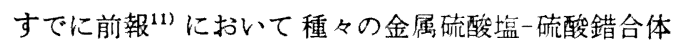
による重合をアセトアルデヒドについて検討したので, 本研究ではこれを省略し, 硫酸マグネシウム一硫酸錯合体 を触媒として種々の検討を行なった。

\section{1 .1 触媒量の影稫}

結果をTable 1 に示す。iso-プチルアルデヒドの重

Table 1. Effect of catalyst concentration on the polymerization of various aldehydes. (Polymerization: $-78^{\circ} \mathrm{C}, 20 \mathrm{hr}$ )

\begin{tabular}{|c|c|c|c|c|c|}
\hline Exp. No. & Aldehyde & Solvent & Catalyst $(\%)$ & Conversion $(\%)$ & {$\left[r_{1}\right]^{*}$} \\
\hline PN-14 & \multirow{3}{*}{$n$-Butyraldehyde } & - & 0.05 & 67.7 & 0.209 \\
\hline PN-9 & & - & 0.1 & 73.7 & 0.204 \\
\hline PN-1 & & - & 0.5 & 79.2 & 0.216 \\
\hline PI-15 & \multirow{4}{*}{ iso-Butyraldehyde } & $n$-Hexane $50 \%$ & 0.05 & 29.5 & - \\
\hline PI-14 & & $"$ & 0.1 & 87.3 & - \\
\hline PI-5 & & $"$ & 0.5 & 79.3 & - \\
\hline PI-16 & & $"$ & 1.0 & 67.8 & - \\
\hline $\mathrm{PM}-1$ & \multirow{3}{*}{ Methoxybutyraldehyde } & - & 0.1 & 26.9 & 0.078 \\
\hline $\mathrm{PM}-2$ & & - & 0.5 & 21.3 & 0.063 \\
\hline $\mathrm{PM}-3$ & & - & 1.0 & 23.0 & 0.102 \\
\hline
\end{tabular}

* For poly ( $n$-butyraldehyde), the values of this column mean $\eta_{p s} / c$ at $c=0.5 \mathrm{~g} / 100 \mathrm{~m} l$ in chloroform containing $2 \%$ of $\beta$-naphthyl amine (at $20^{\circ} \mathrm{C}$ ), and for poly (methoxy butyraldehyde), the values are $[\eta]$ in methyl ethyl ketone (at $27.6^{\circ} \mathrm{C}$ ). Poly (iso-butyraldehyde) was completely insoluble in any solvent, so the viscosity was not measured. 
合では, 重合後のポリマーの取扱の容易さの点から, 溶 掖重合によった。 $n$-および iso-ブチルアルデヒドでは 重合によりかたいポリマーが得られ，特に後者に扔いて 著しいが,メトキシブチルアルデヒドの重合では粘着性 刀弾性体が得られる。
PI-15 の例を除いては，一般に触媒量が重合率および 生成ポリマーの粘度に及ぼす影響はほとんど見られな い。メトキシブチルアルデヒドの重合率の低いことは 特徴的であり，側鎖にある電子吸引性基の影響が考えら れる。

Table 2. Effect of polymerization time on the polymerization of various aldehydes.

(Catalyst: $0.5 \%$, Polymerization: $-78^{\circ} \mathrm{C}$ )

\begin{tabular}{|c|c|c|c|c|c|}
\hline Exp. No. & Aldehyde & Solvent & $\begin{array}{c}\text { Polymerization } \\
\text { time (hr) }\end{array}$ & $\begin{array}{c}\text { Conversion } \\
(\%)\end{array}$ & {$[\eta]^{*}$} \\
\hline $\mathrm{PN}-18$ & \multirow{3}{*}{$n$-Butyraldehyde } & - & 2 & 74.4 & 0.213 \\
\hline PN-19 & & - & 4 & 64.2 & 0.266 \\
\hline PN-14 & & - & 20 & 67.7 & 0.209 \\
\hline $\mathrm{PI}-12$ & \multirow{3}{*}{ iso-Butyraldehyde } & $n$-Hexane $50 \%$ & 2 & 37.6 & - \\
\hline PI-13 & & $"$ & 4 & 79.8 & - \\
\hline PI-5 & & " & 20 & 79.3 & - \\
\hline $\mathrm{PM}-13$ & \multirow{3}{*}{ Methoxybutyraldehyde } & - & 2 & 16.5 & 0.135 \\
\hline PM-12 & & - & 4 & 11.6 & 0.072 \\
\hline $\mathrm{PM}-2$ & & - & 20 & 21.3 & 0.063 \\
\hline
\end{tabular}

* Refer to the foot-notes of Table 1

Table 3. Effect of solvent on the polymerization of various aldehydes.

(Catalyst: $0.5 \%$, Polymerization: $-78^{\circ} \mathrm{C}, 20 \mathrm{hr}$ )

\begin{tabular}{|c|c|c|c|c|c|}
\hline Exp. No. & Aldehyde & \multicolumn{2}{|c|}{ Solvent } & Converision $(\%)$ & {$\left[\gamma_{i}\right]^{*}$} \\
\hline $\mathrm{PN}-4$ & \multirow{6}{*}{$n$-Butyraldehyde } & $n$-Hexane & $20 \%$ & 81.4 & 0.214 \\
\hline $\mathrm{PN}-2$ & & $"$ & $50 \%$ & 79.5 & - \\
\hline PN-3 & & " & $80^{\circ}$ & 42.3 & 0.261 \\
\hline PN-6 & & Toluene & $20 \%$ & 45.5 & 0.252 \\
\hline $\mathrm{PN}-7$ & & $"$ & $50 \%$ & 37.7 & - \\
\hline $\mathrm{PN}-8$ & & $"$ & $80 \%$ & 20.1 & 0.218 \\
\hline PI-4 & \multirow{7}{*}{ iso-Butyraldehyde } & $n$-Hexane & $20 \%$ & 67.2 & - \\
\hline PI-5 & & " & $50 \%$ & 79.3 & - \\
\hline PI-6 & & $"$ & $80 \%$ & 27.0 & - \\
\hline PI-7 & & Toluene & $20 \%$ & 17.9 & - \\
\hline PI-8 & & " & $50 \%$ & 5.8 & - \\
\hline $\mathrm{PI}-81 * *$ & & $"$ & $50 \%$ & 56.2 & - \\
\hline PI-9 & & $"$ & $80 \%$ & 69.8 & - \\
\hline $\mathrm{PM}-4$ & \multirow{6}{*}{ Methoxybutyraldehyde } & $n$-Hexane & $20 \%$ & 57.4 & 0.126 \\
\hline$P M-5$ & & $"$ & $50 \%$ & 15.4 & 0.069 \\
\hline PM -6 & & $"$ & $80 \%$ & 36.2 & 0.127 \\
\hline $\mathrm{PM}-7$ & & Toluene & $20 \%$ & 26.2 & 0.094 \\
\hline$P M-8$ & & " & $50 \%$ & 5.4 & 0.074 \\
\hline PM-9 & & " & $80 \%$ & 7.0 & 0.050 \\
\hline
\end{tabular}

* Refer to the foot-notes of Table 1

** Polymerization trap was shakened during distillation of iso-butyraldehyde under vacuum 


\section{1 .2 重合速度}

この触媒によるアセトアルデヒドの重合においいは, 重合速度がかなり早く, $-78^{\circ} \mathrm{C}, 4$ 時間の重合でほぽ一 定の重合率に達することを認めた ${ }^{11}$ 。アルデヒドの種類 に対応して重合速度がどのように変わるかを調べた結果 が Table 2 である。いずれの場合にも重合速度は大で あり,アセトアルデヒドの重合と同様な傾向が見られる。

\section{1 .3 溶媒の影霎}

低誘電率の溶媒を用いた実駼結果を Table 3 に示す。 一般に, 溶媒量の増加に応じて重合率低下の傾向が認的 られ、また, $n$-へキサンを用いた場合はトルェンを溶媒 とした場合より收率よくポリマーが得られる。

ビニルモノマーの共存下では, Table 4 に示すような 結果が得られる。アセトアルデヒドの重合 ${ }^{11} に$ における 同様に, カチオン試薬に対する両ビニルモノマーの挙動 の差買の影響が見られ，また赤外吸収スペクトルは，ビ ニルモノマー不存時に得られるポリマーのそれと同じで あり, 共重合は起こっていないものと考えられる。

\subsection{4 重合温度の影響}

アルデヒドの種類が異なれば，重合反応以外の副反応 の起こる割合や重合可能な上限温度が変化し, 重合温变 の影響はアルデヒドの種類によって異なる。ブチルアル デトド類について，一定重合条件下で重合温度の影響を 調べた結果を示すと Table 5 のようである。 $-30^{\circ} \mathrm{C} に$ 扔ける重合では, iso-ブチルアルデヒドの場合に少量の ポリマーが得られるが, 他のアルデヒドではポリマーが 得られない。また， $-50^{\circ} \mathrm{C}$ で重合して得られたポリマ

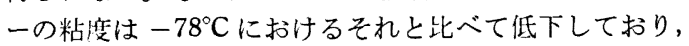
特に n-ブチルアルデヒドの場合に著しい。

\subsection{6 触媒分散の影響}

本研究に㧍ける重合は, すべて静置重合法であり, し たがって, 固体触媒は常に重合容器の低部に固まって存 在する。アセトアルデヒドの重合では, 固体触媒を分散 させると得られるポリマーの重合度が著しく增大するこ とを認めた ${ }^{11}$ 。ここでも前報 ${ }^{11}$ 同様の方法によりガラ 又管を充てん物として触媒分散の影響を調べた。結果を

Table 4. Polymerization of various aldehydes in the presence of vinyl monomers.

(Catalyst: $0.5 \%$, Polymerization: $-78^{\circ} \mathrm{C}, 20 \mathrm{hr}$ )

\begin{tabular}{|c|c|c|c|c|c|}
\hline Exp. No. & Aldehyde & Vinyl mor & omer & Conversion (\%) & {$\left[r_{j}\right]^{*}$} \\
\hline $\mathrm{PN}-11$ & \multirow{2}{*}{$n$-Butyraldehyde } & $\mathrm{VAc}^{* *}$ & $20 \%$ & 59.7 & 0.127 \\
\hline $\mathrm{PN}-12$ & & $n-\mathrm{BVE}^{* * *}$ & $20 \%$ & 69.0 & 0.164 \\
\hline $\mathrm{PI}-17$ & \multirow{2}{*}{ iso-Butyraldehyde } & VAc & $50 \%$ & 26.1 & - \\
\hline PI-18 & & $n$-BVE & $50 \%$ & 65.9 & - \\
\hline $\mathrm{PM}-15$ & \multirow{2}{*}{ Methoxybutyraldehyde } & VAc & $20 \%$ & 28.5 & 0.115 \\
\hline PM-16 & & $n$-BVE & $50 \%$ & 54.9 & 0.116 \\
\hline
\end{tabular}

* Refer to the foot-notes of Table 1, ** VAc: Vinyl acetate, *** $n$-BVE: $n$-Butyl vinyl ether

Table 5. Effect of polymerization temperature on the polymerization of various aldehydes. (Catalyst: $0.5 \%$, Polymerization : $5 \mathrm{hr}$ )

\begin{tabular}{|c|c|c|c|c|c|}
\hline Exp. No. & Aldehyde & Solvent & $\begin{array}{l}\text { Polymerization } \\
\text { temperature }\left({ }^{\circ} \mathrm{C}\right)\end{array}$ & $\begin{array}{c}\text { Conversion } \\
(\%)\end{array}$ & {$\left[\eta_{1}\right]^{*}$} \\
\hline $\mathrm{PN}-1$ & \multirow{3}{*}{$n$-Butyraldehyde } & - & -78 & 79.2 & 0.216 \\
\hline $\mathrm{PN}-22$ & & - & -50 & 48.2 & 0.037 \\
\hline $\mathrm{PN}-5$ & & - & -30 & $\ldots * *$ & - ** \\
\hline PI-5 & \multirow{3}{*}{ iso-Butyraldehyde } & $n$-Hexane $50 \%$ & -78 & 79.3 & - \\
\hline PI-10 & & $"$ & -50 & 10.6 & - \\
\hline $\mathrm{PI}-11$ & & " & -30 & 2.5 & - \\
\hline PM-2 & \multirow{3}{*}{ Methoxybutyraldehyde } & - & -78 & 21.3 & 0.063 \\
\hline PM-10 & & - & -50 & 23.4 & 0.050 \\
\hline PM-11 & & - & -30 & -** & - ** \\
\hline
\end{tabular}

* Refer to the foot-notes of Table 1 ,

* High polymer was not obtained. 
Table 6. Effect of dispersing solid catalyst on the polymerization of various aldehydes.

Filler: Glass tube, Catalyst : $0.5 \%$,

Bulk polymerization: $-78^{\circ} \mathrm{C}, 20 \mathrm{hr}$

\begin{tabular}{c|c|c|c}
\hline Exp. No. & Aldehyde & $\begin{array}{c}\text { Coversion } \\
(\%)\end{array}$ & {$[\eta]^{*}$} \\
\hline PN-13 & $\begin{array}{c}n \text {-Butyr- } \\
\text { aldehyde }\end{array}$ & 66.6 & 0.240 \\
PM-14 & $\begin{array}{c}\text { Methoxy- } \\
\text { butyraldehyde }\end{array}$ & 35.4 & 0.177 \\
\hline
\end{tabular}

* Refer to the foot-notes of Table 1

Table 6 に示す。いずれの場合にす生成ポリマーの粘淁 が若干增大することが認められるが，アセトアルデヒド の重合の場合に和けるほど著しくない。

\subsection{7 その他のアルデヒドの重合}

クロラール，アクロレインおよびクロトンアルデヒド について、触媒として硫酸マグネシウム一硫酸錯合体 $1.0^{\circ}$ 。 を用い, $-78,-50,0^{\circ} \mathrm{C}$ および $30^{\circ} \mathrm{C}$ に扔いて 塊状重合文試みたが，いずれの場合も5 日後においても
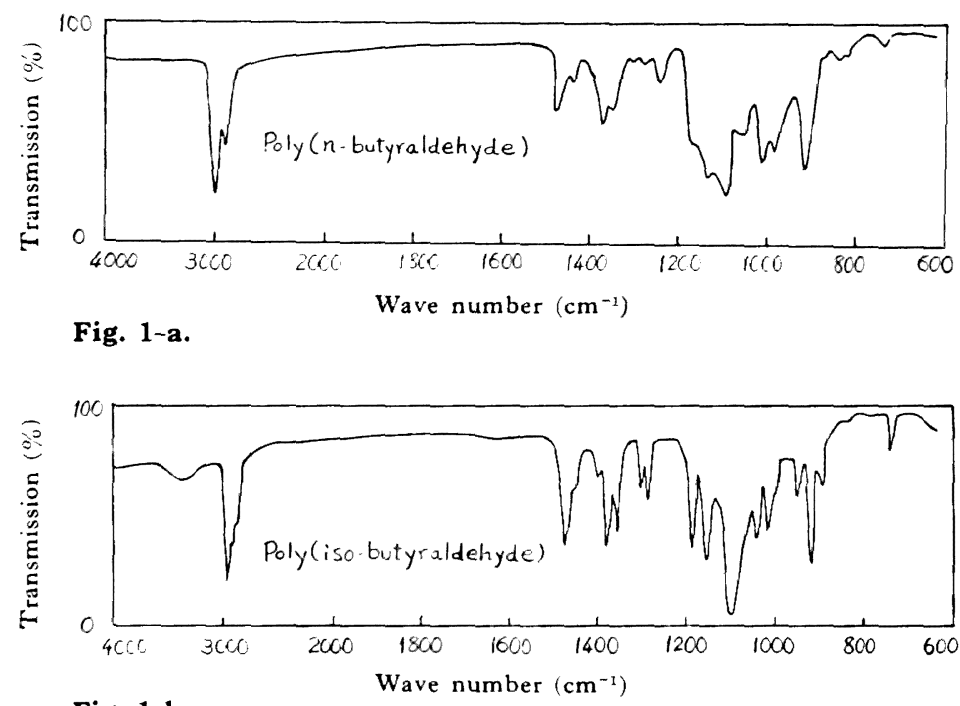

Fig. 1-b.

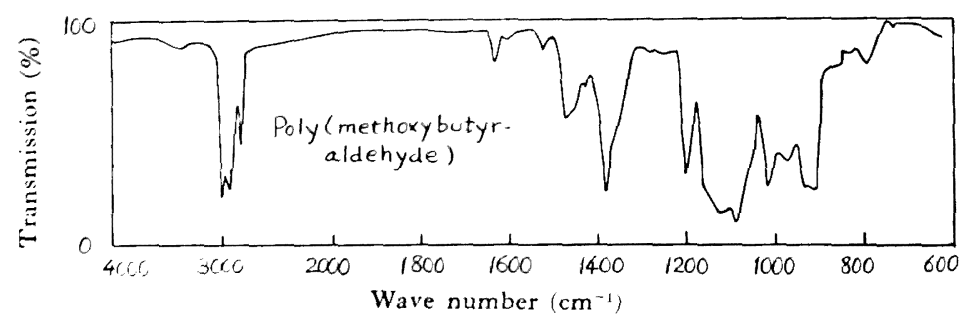

Fig. 1-c.

Fig. 1. Infrared spectra of polyaldehydes.

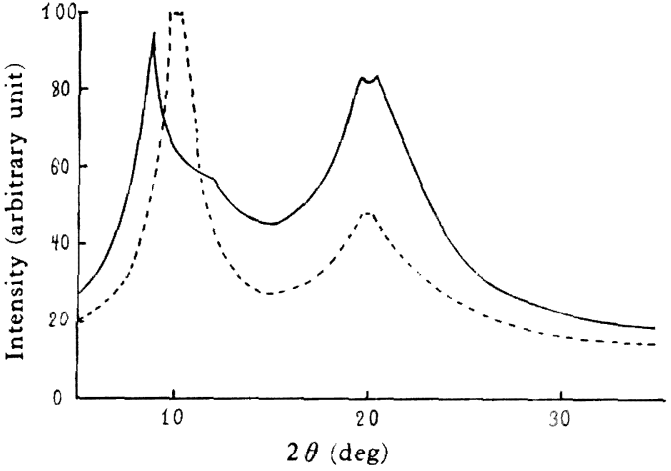

Full line: Poly (n-butyraldehyde)

Dotted line: Poly (iso-butyraldehyde)

Fig. 2. X-ray diffraction diagram of polyaldehydes. ポリマーの生成はみられなかった。

\section{2 ポリマーの構造, 性質}

\section{2 .1 ポリマーの構造}

本研究で得られた各アルデヒドポリマーの赤外吸収ス ペクトルをFig. 1 に示す。nー扩よび iso-ブチルアルデヒドポリマーの赤外 吸收スペクトルは Novak ら"によっ て示されたものとほぼ一致する。また メトキシブチルアルデヒドのポリマー では， $2820 \mathrm{~cm}^{-1}$ にメトキシのメチル 基の伸縮に基くと思われる強い吸収が みられる。

nーおよび isoーブチルアルデヒドポ リマーの X 線回折强度曲線は Fig. 2 のようである。これらの湘定試料は乾 燥後のポリマーをそのまま用いてお り, 溶媒抽出などの処理は行なってい ない。n-ブチルアルデヒドのポリマー は, 必ずしも高結晶性しはいいがたい が,トリェチルアルミニウム童触媒と して重合して得られた結晶性ポリマー の X 線回折强度曲楾 ${ }^{18)}$ 上の比較から 一応結晶性であると考えられる。isoブチルアルデヒドのポリマーは, トリ エチルアルミニウムを触媒として得ら れた結晶性ポリマー ${ }^{18)}$ と類似の, きわ めて鋭い回折强度曲線交す。

\section{2 .2 ポリマーの性質}

種々の有機溶媒に対するポリマーの 室温に括ける溶解性を検討した結果は 次のようである。

メトキシブチルアルデヒドのポリマ 一ーは, アセトン,メタノール，クロロ 
ホルム、トルェンおよび酢酸エステルなど広範囲の溶 媒に可溶であるが, $n$-ブチルアルデヒドのポリマーはク ロロホルムに溶解するのみであり，また，iso-ブチルア ルデヒドのポリマーはクロロホルムで膨潤するにすぎ ず，可溶な嚓媒は見亦たらない。

nー および iso-ブチルアルデヒドのポリマーはかなり 不安定であり，室温放置によっても著しい分解を示す。 また, $n$-ブチルアルデヒドのポリマーはクロロホルム溶 液として $20^{\circ} \mathrm{C}$ で粘度測定中にも著しい粘度低下を起こ す。その状態 Fig. 3 に示すごとくであり,これは,引ナフチルアミンの $20 \%$ クロホルム溶液を溶媒として 測定を行なうこ上によりかなり防止できるが，なお，若

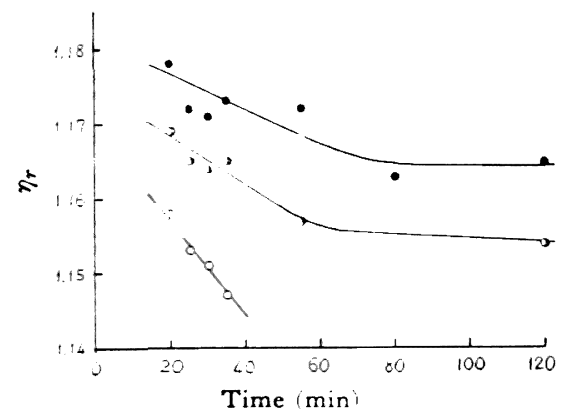

Solvent: Chloroform, Chloroform containing $1 \%$ of $\bar{p}$-naphtylamine, Chloroform containing $2 \% \beta$-naphthylamine

Fig. 3. Decrease of viscosity of poly ( $\boldsymbol{n}$-butyraldehyde) solution.

干の粘度低下は免がれない。メトキシブチルアルデヒト゚ のポリマーでは, 粘变测定中の分解举動はほとんど認め られず, 側㓋に存在する電子吸引性基のために安定性が 向上する上考えられる。

\section{4. 考察}

本研究て取り扱ったアルデヒド類の中， $n$ 一および iso-ブチルアルデヒド，メトキシプチルアルデヒドにお いては，アさトアルデヒト゚の重合に坮いてみられたと同 一傾向の実娩結果が得られた。このことからこれらの アルデヒドの重合はアセトアルデヒト゚の重合において述

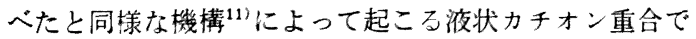
あろうと考えられる。

なお,これらのアルデヒドの重台において, 重合溶媒 の種類が大きな効果をさつことが，3.1.3 でみられた。 すなわち, どのアルデヒドの重合でも $n$-ヘキサンを溶 媒に用いた場合には、トルェンを溶媒に用いた場合より も収率よくポリマーが得られる。両溶媒はともに代表的 な低誘電率の溶媒であり, 誘電率はわずかにトルェンの 方が大きいにかかわらす，このよらな著しい差の現われ
るのは, ベンゼン核を有する芳香族炭化水素と脂肪族飽 和炭化水素のカルボニウムイオンに対する保護効果の差 異に基くものであるが, 特にその差異の著しいiso-ブチ ルアルデヒドでは, その密度がトルエンのそれより小さ く(密度はトルェン>iso-ブチルアルデヒド〉n-ヘキサ ンの順に低下する), かつ本実験のごとく, 溶媒(トルェ ン)をさきに蒸留仕込む静置重合法では, 両者が重合温度 において互に混和せず, 重合は両者の界面, または壁面 (壁面への少量の付着触媒などによる)より始まって, か たい膜面を形成し, 存在する固体不均一触媒が有効に利 用されずに，それ以上の重合の進まないことも一因で ある。このことはモ, マー仕込中, 真空下で重合系妾振 とらしてモノマーを分散させると重合は容易に進行し, Table 3 の PI-8 と PI-81 の比較にみられるごとく, 影著に重合率の增加することから確か内られる。

カルボニル基の炭素原子につく側鎖がアルデヒド類の カチオン重合に著しい影響をもつことは本実験の結果か ら明らかである。

まず, アルデヒドのカチオン重合性は $n$-, iso-ブチル アルデヒド〉メトキシブチルアルデヒド》アクロレイ ン, クロトンアルデヒド, クロラールの順に低下し, 特 にアクロレイン以下では, 金属硫酸塩一硫酸錯合体により 重合が起こらない。すなわち, 電子供給性の側鎖をもつ アルデヒドではカチオン重合が容易であり, 逆に, 電子 吸引性の側鎖のものではカチナン重合が困難となる。電 子供給性の側鎖があれば, 荷電の内部分散の効果が現わ れ, そのためカルボニウムイオンが安定化されるが, 電 子吸引性の側鎖ではこれと逆の傾向をもたらす。それら え, カルボニウムイオン生成の難易がこれらのアルデヒ ドのカチオン重合性に大きな差異をもたらすものと考え られる。

文献に現われた例をみても、アクロレインはラジカル， カチオンおよびアニオンのいずれの機構によっても重合 が可能であり，カチオン重合の触媒としては，たとえば， $\mathrm{BF}_{3} \cdot$ エーテラート, 硫酸・エーテラートなどが有効で あるが $\mathrm{AlBr}_{3}$ では重合せず，また， $\mathrm{BF}_{3} ・$ ，あるいは硫 酸・エーテラートを触媒に用いる場合でもその使用量は 比較的多量(前者で $5 \%$, 後者で $2 \mathrm{vol} \%$ ) であって, 重 合温度も $0^{\circ} \mathrm{C}$ 以上で行なっている ${ }^{12)}$ 。クロラールもカチ オン, アニオン直合ともに可能であり ${ }^{13)}$, 有機金属化合 物を触媒として結晶性のポリマーも得られているが10)， たとえばカチオン触媒である硫酸では, クロラールに対 して4 倍量が用いられ, 室温, 4 日間の重合条件である。 それゆえこれらのアルデヒドのカチオン重合条件は, 本研究の 重合条件よりはるかに激しいものといえよう。 また, クロトンアルデヒドの高压重合 ${ }^{14)}$ 。カチオン ${ }^{15)}$ お よぴアニオン重合 ${ }^{18), 17)}$ も知られているが, $\mathrm{BF}_{3}$ ・ エーテ ラートを用いるカチオン重合では, 主として重合が炭素- 
炭素の二重結合で起こり，しかも $-30^{\circ} \mathrm{C}$ 以下ではポリ マーの生成しないことが認为られている。

次に側鎖の影響が 現われるのはポリマーの構造であ る。金属硫酸塩一硫酸錯合体によるアセトアルデヒドの 重合では, 非晶性のポリマーが得られたが'11) $n$ - および iso-ブチルアルデヒドの重合では結晶性ポリマーが得ら れる。これは主として bulky な側鎖の存在によるもの であり, Vogl がルイス酸を触媒に用いて得た結果” と 一致する。

構造に関連してポリマーの溶解性も著しい影響を受け る。非晶性のアセトアルデヒドおよびメトキシブチルア ルデヒドのポリマーはいずれも広範囲な溶媒に可溶であ るが, 結晶性の $n$ - および iso-ブチルアルデヒドのポリ マーの溶解性は極端に悪い。

ポリマーの安定性も側鎖によって大きな影響老受け る。特にn-扔よび iso-ブチルアルデヒドポリマーで は安定性が覀い。これらのアルデヒドポリマーではイオ ン的な分解反応が起こりやすいが，側鎖つ電子供給性は これに対して大きな効果をもつ。すなわち，電子供給性 の大きい側鎖をもつものほどアセタール結合における酸 素の電子密度が高くなり, イオン的な分解反応を起こし やすくなる。アセトアルデヒド,メトキシブチルアルデ ヒドのポリマーに比して, $n$ - および iso-ブチルアルデ ヒドポリマーの安定性が低下する結果は, これとよく対 応している。

付 記：有益なご討論をいただいた京都大学工学部古川淳二 教授，発表の機会を与えられた会社当局抢上び実験に協力され
た徳永昭夫君化感謝します。な㧍，本研究は高分子研究発表会 (1962 年 7 月, 神戸)において発表した。

\section{文献}

1) P. W. Bridgman, J. B. Conant: Proc. Nat. Acad. Sci., 15, 680(1929)

2) J. B. Conant, C. O. Tonberg: J. Am. Chem. Soc., 52, 1659(1930)

3) J. B. Conant, W. R. Peterson: J. Am. Chem. Soc., 54, 628(1932)

4) A. Novak, E. Whalley : Can. J. Chem., 37, 1710, $1718(1959)$

5) V. M. Zhulin, M. G. Gonikberg: V. skomol. Soed., 3, 262(1961)

6) V. M. Zhulin, M. G. Gonikberg: Vyskomol. Soed., 3, 268(1961)

7) O. Vogl: J. Polymer Sci., 46, $261(1960)$

8）宮川高明，山本 襄：高分子学会第 11 回年次大 会 (1962. 5. 名古屋)

9) G. Natta, G. Mazzanti, P. Corradini, I. W. Bassi : Makromol. Chem., 37, 156(1960)

10) J. Furukawa, T. Saegusa, H. Fujii : Makromol. Chem., 44 46, 398(1960)

11) 滝田 博, 野呂 健: 高化, 20, 705(1963)

12) R.C. Schulz: Makromol. Chem., 17, 62(1956)

13) A. Novak, E. Whalley: Trans. Faraday Soc., $55,1490(1959)$

14）井本立也, 太田忠甫, 神原次郎：日化，82，492 (1961)

15）祖父江寛, 斎藤吉民：工化，65，1630(1962)

16) J. N. Koral: J. Polymer Sci., 61, S-38 (1962)

17）太田忠甫, 高橋 功：日本化学会中国四国大会 (1962. 8. 德島)

18) H. Sobue, H. Kubota: Bull. Chem. Soc. Japan, $34,883(1961)$

\title{
Polymerization of Aldehyde with Solid Catalyst \\ II. Polymerization of Various Aldehydes with Metal Sulfate-Sulfuric Acid Complex
}

\author{
By Hiroshi Takida* and Ken Noro*
}

\begin{abstract}
Polymerization of $n$-butyraldehyde, iso-butyraldehyde and methoxybutyraldehyde were carried out by using magnesium sulfate-sulfuric acid complex as catalyst in the temperature range between -30 and $-78^{\circ} \mathrm{C}$.

At $-30^{\circ} \mathrm{C}$, only iso-butyraldehyde polymerized slightly, and at $-78^{\circ} \mathrm{C}, n$-butyraldehyde and iso-butyraldehyde polymerized to relatively high conversion, but the polymerization of methoxybutyraldehyde was restricted in low conversion. Generally, effect of catalyst concentration on the polymerization of aldehydes was not remarkable in the range of $0.1 \sim 1.0 \%$. The rate of polymerization was rapid considerably. Viscosities of polymers were increased some what by dispersing solid catalyst but the increase of viscosities was not so remarkable as in the polymerization of acetaldehyde. Poly (methoxybutyraldehyde), soluble in various solvents, was sticky elastomer, so it is considered to be amorphous. Poly ( $n$-butyraldehyde) was soluble only in chloroform but poly (iso-butyraldehyde) was insoluble in various solvents. They were confirmed to be crystalline from the results of $\mathrm{X}$-ray diffraction patterns. Chloral, acrolein and croton aldehyde could not be polymerized with metal sulfate-sulfuric acid complex.
\end{abstract}

* Central Research Laboratory, The Nippon Synthetic Chemical Industry Co., Ltd. (156, Kamikema, Amagasaki, Hyogo 